\title{
Teocomunicação
}

Programa de Pós-Graduação em Teologia

Escola de Humanidades

Porto Alegre, v. 48, n. 1, p. 82-96, janeiro-junho 2018

\section{Human Transcendence as a Locus of Revelation and Foundation for Theological Work: Implications from Rahner's Hearer of the Word*}

\author{
A transcendência humana como lugar de Revelação e fundamento do \\ fazer teológico: Implicações da obra Ouvintes da Palavra, de K. Rahner
}

\author{
Leandro Luis Bedin Fontana**
}

\begin{abstract}
This article concerns the complex relation between the heteronomous authority of divine revelation and human autonomy, particularly having regard to the context of Western, secularized, religiously plural societies. In the face of the current fragmentation of meaning and the crisis of morality, and considering that individuals must take on the responsibility for their own life projects and decisions themselves, they can no longer cope without personal autonomy to form their own frames of reference, rather than deriving them from religions, as in the past, whose doctrines have become alien to them. In Hearer of the Word, Rahner raises human transcendence to a category in which human autonomy and God's ultimate Word meet on the level of Being, of existence, where meaning is reintegrated, the lively, original experience of Revelation is recovered, and the apparent contradiction between faith and lifeworld can be overcome through an authentic form of religious life.
\end{abstract}

Keywords: Revelation. Autonomy. Secularity. Transcendence. Theology.

\section{RESUMO}

O presente artigo aborda a complexa relação entre a autonomia humana e a autoridade heterônoma da Revelação divina, dedicando particular atenção ao contexto das sociedades secularizadas e religiosamente plurais do Ocidente. Considerando a fragmentação de sentido, a crise da moralidade, e a necessidade de que os indivíduos desses contextos assumam completa responsabilidade por seus projetos de vida e decisões, tornou-se impossível prescindir da autonomia pessoal que possibilita a cada um/a poder definir os próprios marcos de referência, ao invés de delegar essa tarefa às religiões, como no passado, o que tem dado origem, não raro, a conflitos existenciais. Em Ouvintes da Palavra, Rahner eleva a transcendência humana a uma categoria na qual a autonomia humana e a Palavra de Deus encontram-se no plano do Ser, da existência, onde o sentido é reintegrado, a experiência viva originária da Revelação é recuperada e a aparente contradição entre fé e mundo da vida pode ser superada através de uma vida religiosa e espiritual autêntica.

Palavras-chave: Revelação. Autonomia. Secularidade. Transcendência. Teologia.

* The present study is an expanded version of a talk delivered in an interreligious theological colloquium between Christian, Jewish, and Islamic scholars held at the University of Istanbul on 11 September 2012.

** Licenciado em Filosofia (2001) pela FAFIMC, Viamão, RS. Bacharel em Teologia (2008) pela PUCRS. Doutor em Teologia (2016) pela Philosophisch-Theologische Hochschule Sankt Georgen, Frankfurt, Alemanha. Atualmente trabalha como pesquisador bolsista do Programa Nacional de Pós-Doutorado, vinculado ao Programa de Pós-Graduação em Teologia da PUCRS. <lefontana@gmail.com>. 


\section{INTRODUCTION}

After the earthquake brought about by Enlightenment, followed by the powerful waves of Atheism and Secularism and the prophecies of the burial of religion, many scholars diagnose today not only an increasing search for religious experiences of all sorts, but also a different sensitivity as to the import of religion for a sound society. ${ }^{1}$ Alongside the thesis of the "decline of religion" in modern societies, it has been also predicted that, if at all religions are to be allocated a place in society, then in the private sphere of individuals, rather than on the public square of democracy. No longer should they exert any influence in the public sphere, given their great potential for violence. But the thesis of the "privatization of religions" has been equally disclaimed by a great number of scholars. Among them are prominent names such as Jürgen Habermas, Hans Joas, David Martin, and José Casanova. Indeed, a joint work involving several scholars from different disciplines, demonstrates how important a role religions nowadays play in the public domain and, particularly, in public discourses. ${ }^{2}$ To be sure, the authors are informed about the ambivalence of religion, particularly as regards the various forms of new fundamentalisms that have emerged in the last decades. On the other hand, they are just as aware of the ambiguities of modernity or, to be more precise, the ambiguities of multiple modernities. Be that as it may, there is a growing consciousness that a fruitful interplay between religion and modern societies is extremely required.

Major difficulties may arise, however, in secularized societies, when it comes to the question of the heteronomous authority of revealed truths, insofar as these are invested with such a normative character that the autonomy of the individual seems to be put in jeopardy. For what seems to give rise to major fears, misunderstandings, and conflicts, in this case, is ultimately the claim that divine revelation would foil the ambitious project of modernity at the core of which are the ideals of human freedom, autonomy, and self-determination.

Therefore, the question to be examined in the present paper could be put as follows: Why should citizens of a free, plural, and post-metaphysical society still accept the mythological truths of religions, let alone believe in them or perhaps let one's own project of life be determined by them? After all, they live in democratic societies in which moral life is based on the principles of human rights and they find it hard to square their enlightened minds with doctrinal, authoritarian assertions. To put it more positively, can God's revelation be accepted by human beings without having to give up the autonomy of their freedom or betray their reason?

The German Catholic theologian Karl Rahner counts as one of the scholars who had a very good sense of this problem and attempted to tackle it fairly early in his theological journey. Therefore, "Hearer of the Word", one of his first works, will be examined with the aim of making his valuable contribution to this issue fruitful for the current discussion on it. The analysis of his work will suggest two further questions: what is to be expected from the human being as addressee of revelation and what from theology as the rationality of faith before the Word of God? Or, what should be the interrelationship between theology and the enlightened, not rarely, secularized human being, in her/his personal quest for meaning, autonomy, and redemption?

\footnotetext{
CASANOVA, J. Public Religions Revisited, p. 202; HABERMAS, J. Glauben und Wissen, p. 21; JOAS, H.; WIEGANDT, K. (eds.) Säkularisierung und die Weltreligionen; MARTIN, D. On Secularization.

2 CASANOVA, J.; JOAS, H., Religion und die umstrittene Moderne.
} 


\section{RAHNER'S ORIGINAL ATTEMPT IN HEARER OF THE WORD}

Rahner's Work is, beyond doubt, a wellspring of knowledge and a source of inspiration for theological thinking. It goes without saying that to carry out a study on revelation taking all his writings on that subject into account would be unfeasible and meaningless. The selection of this early work of his, Hearer of the Word, has three chief reasons. Firstly and most importantly, it was motivated by the supposition that Rahner provides, in this writing, a very adequate approach to revelation and precisely identifies the main issues related to this topic. Secondly, even though his understanding of revelation has evolved over the years, the solutions suggested in this writing have not yet lost its originality and are, therefore, worthy of deeper consideration in contemporary theology. Thirdly, it is an attempt to recover a work that has somehow faded into oblivion over the years, not least because of Rahner's more recent writings on the same topics treated in Hearer of the Word. Bearing in mind the purpose and the scope of this paper, the summary exposition of a few selected ideas of the work should suffice.

\subsection{The Purpose of Hearer of the Word}

The fundamental issue underlying Hearer of the Word is both the search for a common foundation for all human sciences and the status of theology relative to other sciences, with a particular focus being on philosophy of religion. By doing so, Rahner intensifies even more the predicament between faith and reason ${ }^{3}$, as posed above, insofar as it inquires about the epistemological foundation of all sciences, including theology. Rahner was well aware that simply juxtaposing faith in opposition to reason, thereby granting the former a more privileged status over the latter, would amount to declare theology as having a special status among sciences, which was, for him, no longer possible on account of the intense debate over the Wissenschaftlichkeit (scientificity) of academic disciplines going on in his days. On the other hand, he was just as aware of the peculiarity of theology, owing to its most fundamental task of hearing and interpreting the Word of God, rather than human words, which is the case of other sciences, including philosophy of religion. Caught up in that dilemma, Rahner ventures an answer to this vexed issue.

\subsection{A Brief Contextualization}

The special occasion that prompted him to look into this subject more deeply was the preparation for a lecture series on Fundamental Theology and Philosophy of Religion at the Theological Faculty of Salzburg in 1937. Hearer of the Word is, therefore, basically, the edited publication of those lectures. The first edition of this writing came out in 1941 whereas the second, reedited considerably by Rahner's assistant Johann Baptist Metz, in 1963. Both editions have been recently reprinted in the collection of Rahner's complete works ${ }^{4}$.

\footnotetext{
${ }^{3}$ Therefore, lest the entirety of this paper and the particular question being examined be lost sight of, if helpful, the reader may replace, in the following, the words philosophy of religion with reason and theology with faith.

${ }^{4}$ Cf. RAHNER, K. Hörer des Wortes: Zur Grundlegung einer Religionsphilosophie (1941); RAHNER, K. Hörer des Wortes: Zur Grundlegung einer Religionsphilosophie, ed. Johannes Baptist Metz (1963); RAHNER, K. Hörer des Wortes: Schriften zur Religionsphilosophie und zur Grundlegung der Theologie, ed. Albert Raffelt, (1997).
} 
Rahner had been working on the topics of revelation and human nature since 1934, especially in the context of his study and reception of the Nouvelle Théologie $e^{5}$. Moreover, it was particularly through the texts by the Belgian Jesuit Joseph Maréchal that Rahner gained very original insights both to work on his theory of cognition and his metaphysics and to begin his lifelong project of combining Kant's transcendental philosophy with Thomas Aquinas' theology, an endeavor that, in turn, gave rise to his transcendental theology ${ }^{6}$. Finally, the significant influence of Martin Heidegger's ontological approach during Rahners philosophy study may not be forgotten. The notion of "existentials" and the ontological difference in Rahner's theology are just two examples to illustrate that influence ${ }^{7}$.

Though brief, this contextualization might have served the purpose of helping us create a more comprehensive picture as regards the assumptions, premises, and implicit presuppositions going through Rahner's mind while writing down those lectures.

\subsection{The "Potentia Oboedentialis" as Ontological Structure of Being}

In "Hearer of the Word", Rahner searches out for a common foundation not only between theology and philosophy of religion, but to all human sciences. It appears to him highly unlikely that each science should constitute itself of its own accord and due to own reasons. For, as he sees it, beyond the material and formal objects of the various sciences there must be something which lies at the very foundation of them all. After all, sciences are much more than a system of valid assertions. Primarily, a science is the consequence of one of the most characteristic, essential acts of human beings: the act of inquiring (13f/18f/12) ${ }^{8}$. Therefore, since doing science is an essential human act, the common foundation amongst different sciences must be, according to Rahner, metaphysics (or metaphysical anthropology). The reason he provides to support his claim is that inquiring about the essence of science amounts to inquire about the essence of Being 9 . Accordingly, an epistemological question is, at the same time, a metaphysical one, which is, in turn, a question about being, about the human being (12/17/10).

What is achieved by Rahner through this opening presupposition is to ground science, all science, in the ontological structure of the human being. To define the human being as someone who essentially inquires after being is the same as affirming that she/he necessarily does science - understood here in its widest sense (14/19/14). Having laid the deepest possible foundation for science, Rahner sets about the complex relation between philosophy of religion and theology.

Assuming that the object of philosophy of religion is the knowledge of God, of absolute Being, it is possible to affirm that metaphysics, conceived as universal ontology, and philosophy of religion coincide. It is precisely on account of that coincidence, that philosophy of religion is capable of determining "the right relation to God, to the absolute" (15/20/14), which is, as Rahner sees it, one of openness for a possible Word,

\footnotetext{
${ }^{5}$ BATLOGG, A. R. Glauben gibt zu denken, p. 56, 89.

${ }^{6}$ See esp. GREINER, F. Die Menschlichkeit der Offenbarung, p. 73-81; WEGER, K.-H. Karl Rahner, p. 28-37.

${ }^{7}$ BATLOGG, A. R. Glauben gibt zu denken, p. 72-74.

${ }^{8}$ In the following, the page numbers will be given parenthetically in the text. For the reader's convenience the page numbers of all three editions will be given consecutively and in chronological order. So the first page number given in brackets refers to the 1941 edition, the second to the 1963 ed., and the third to the 1997 ed. A few quotes are taken from the English translation by Joseph Donceel (cf. RAHNER, K. Hearer of the Word: Laying the Foundation for a Philosophy of Religion, ed. Andrew Tallon, trans. Joseph Donceel).

9 To do justice to Heidegger's ontological difference, which is adopted by Rahner, Sein has been translated as Being (upper-case) whereas Seiendes as entity or being (lower-case).
} 
for the possibility of a revelation of God out of his free initiative. Since this revelation, being God's Word and not a human one, cannot but take place in human history and be mediated by human words, the human being cannot find it in himself, but is utterly dependent upon human history. Therefore, she/he has, to be referred to, essentially, as a historical being who searches for, is capable of listening to, and keenly awaits God's revelation $(23 / 29 / 26)$.

Being so, philosophy of religion serves as a basis for theology "from below". In a word, philosophy of religion may be said to be the condition of possibility for doing theology. This is certainly not to say that God "depends" on the conditions laid down by philosophy of religion to utter his Word, as he is free to do so when and how he wills. What is meant is, rather, that the potentia oboedientialis, the term coined by Rahner for such capacity of listening, which constitutes the very being of philosophy of religion, is the condition of possibility for a possible revelation.

To sum up, one could say that whereas philosophy of religion may be defined as an "ontology of the potentia oboedientialis"10, theology may be said to be the very act of listening to God's Word. Yet, the point Rahner intends to make here is the existence of a double referentiality between human nature and absolute Being, between God and human beings, which is the object of investigation of the second part of his writing. Whilst, on the part of Being, such reference to human beings is manifest in the form of "clearedness" (Gelichtetheit) ${ }^{11}$ or "luminosity", it can be perceived, on the part of human being, in her/his unconditional openness.

The following quote summarizes what has been exposed so far and closes this section.

The second condition supposed for the possibility of revelation is that human nature must possess an openness for the utterance of ultimate being in the luminous word. This openness is an a priori presupposition for the possibility of hearing such a word. This points to our next task: to infer from the first aspect of our general question about being what it can tell us for a metaphysical anthropology of the human person as a being who is of this nature open for a possible revelation. When, at the beginning of the preceding chapter, we mentioned the three aspects of the general question about being, we formulated the first one as follows: in this question we inquire about being as such, about all being. We must examine not only the content of this question, but also why we must necessarily ask it. Therefore an analysis of this question is also always at the same time an analysis of the being who asks it. Thus we have to make explicit what the first aspect of this question tells us for a metaphysical anthropology. It tells us this: To be human is to be an absolute openness for being, or, to say it in one word, the human person is spirit. The transcendence toward being as such constitutes the basic makeup of human beings. This is the first principle of our metaphysical anthropology $(67 \mathrm{f} / 71 / 82$, translation from RAHNER, 1994, p. 41).

\footnotetext{
${ }^{10}$ See also BATLOGG, A. R. Glauben gibt zu denken, p. 92; RAHNER, Hörer des Wortes, 1997, p. 286.

${ }^{11}$ Gelichtetheit is a term coined by Heidegger in his critique of classic metaphysics to make clear that the truth of Being, which is attained alone by virtue of such clearedness (Gelichtetheit), is more of a process than an original state of affairs. According to him, the greatest mistake of classic metaphysics was to fail to distinguish between Being (Sein) and entities (Seiendes), thereby identifying Being with an entity, something static, even if being were equated with God. Accordingly, the truth of Being or the foundation of metaphysics cannot be an entity, but a process through which entities are cleared, illuminated by Being. Only "at the end" of it can one speak of truth, of clearedness, of unconcealedness of Being (FISCHER, N. Die Gottesfrage im Denken Martin Heideggers, p. 113-16).
} 


\subsection{Doing Theology in the Light of God's Word}

Having laid the solid foundation for the possibility of listening to the Word of God by means of the definition of the human being as spirit, as mind (Geist), as a transcendental being always open to a possible revelation of Being in history, we shall now move to the specific act of listening to the Word, which, in Rahner's view, is the primary task of theology. This section concerns itself with three main issues which shall be summarily dealt with in the following: a) Rahner's general understanding of theology, b) the discipline of theology considered in its relation to other academic disciplines and, by extension, with secular persons or believers of other religious traditions; c) the specific task of theology in the current context.

\subsubsection{The Role of Theology in a Modern World}

As for the first question, Rahner defines theology in a twofold manner. To put it in a nutshell, he makes use of the classic distinction between positive and scholastic theology. Accordingly, whereas the former refers to the absolutely free act of God in revealing himself out of his incommensurable love and, consequently, the message of revelation as such, the latter concerns the act of human thinking over the meaning and the implications of this heard Word (16/21f/16).

As a result - and this touches on the second issue already - theology, in its most original and essential sense, i.e., as God's Word, cannot stand on the same level as other academic disciplines, insofar as it was not and could not have been constituted only by human knowledge, just as others were. Theology is absolutely dependent on the free act of God. In this first sense, there is practically no possibility of a dialogue with other sciences, given that God is free to reveal what he wills, just as it pleased him to, and the theologian has no right whatsoever to change it. This state of affairs, one could say, accords theology a unique status amongst sciences. This is not to be understood in terms of an absolute, infallible authority, but in the sense that, due to its peculiar constitution, its object lies beyond human influence.

In its second dimension, however, as intellectus fidei, theology is bound to engage in discursive argumentation and consider academic rules and methods, just as other disciplines do. Admittedly, Rahner was well informed that the content of God's revelation was already grasped in unity between both auditus and intellectus fidei, as much in its origins as in its transmission. On the other side, he is convinced that, as we receive it anew, "[w]e can and must then subject it to our own inquiring and systematizing thought and integrate it within the totality of all human knowledge, thus setting up the science of theology" (16/21/16, translation from RAHNER, 1994, p. 5). Consequently, if theology wishes to be recognized as an academic discipline in a plural, scientific, and secularized world, it can no longer operate with a premodern concept of authority and justification for its claims. The elucidation of revelation is to be provided by theology through rational argumentation and to be embedded in an academic discourse in the mode of a constructive and critical debate with other sciences, institutions, and religions.

However, this way of proceeding regards principally the formal character of theology. Therefore, the focus must now be shifted to the "inner work" of theology, which leads us to the third question put above, namely the task of theology. Essentially, for Rahner, the business of theology consists in the very act of hearing the Word. For hearing, far from being a once-for-all act, is a permanent, existential process. 
If we start from ourselves, God's revelation cannot be validated either in its actuality, or in its necessity, or in its inner nature. This being the case, we understand at once that an epistemological validation of theology (which should somehow be previous to it) cannot apply to God's word, but only to our listening to it $(17 / 22 / 18$, translation from RAHNER, 1994, p. 5).

As opposed to a concept of revelation whereby the human being would have no role to play other than accepting it passively and submissively, the emphasis is now shifted to God's interlocutor: firstly, whether or not we are capable of hearing God's message just as he wants to disclose it to us, and, secondly, what that listening is all about. Rahner was convinced that neither of the two strong theological currents of his time, viz. liberal and dialectic theology, was in a position to do justice to the Word of God, since both thought of revelation as a correlate of the human being, either a positive one in the case of the former, or a negative one in the case of the latter. If one, however, wants to really hear the content of the message of God, one has to go beyond a model which, in the end, is "nothing but a formal yes or no to the human being" (38/43/46, own translation). ${ }^{12}$ The neo-Scholastic concept of revelation or the Catholic antimodernist attitude did not represent, for him, any alternative either. As can be seen, Rahner noticed very early in his life the need of a reorientation in theological work.

Rahner's underlying concern was to highlight the quest of every person for meaning and transcendence and to make sure that the content of revelation still makes sense to the human being, even to the enlightened reason. This has to be understood in the context of the so called "anthropological turn", that is, a turn whereby "the modern human being established her/himself as reference point, as starting as well as aim point of her/his knowledge and action [...]"13. Rahner was the first Catholic theologian who attempted to carry out this turn in theology. ${ }^{14} \mathrm{He}$ was well-informed as to both the impossibility of postulating any assertion about God within the limits of theoretical reason ${ }^{15}$ and the incompatibility between modern thinking and scholastic metaphysics, particularly due to the gaping abyss between natural and supernatural worlds. Indeed, Rahner affirms emphatically, some years later: "Today dogmatic theology must be anthropology and such an 'anthropological turn' is necessary and fruitful" ${ }^{16}$ That implies, in turn, "to look to human beings themselves with all their prejudices and limitations for the necessary and meaningful starting point as well as the ground of the possibility of every theological assertion". ${ }^{17}$

Thus, the basic prerequisite to understand revelation in modern and contemporary theology is, and remains, both the freedom of God in revealing himself and the freedom of the human being in searching for ultimate truth, in experiencing faith, and in listening to God's message. In that way, the task of doing theology, that is, listening to and reflecting on God's Word, belongs, theoretically, not only to actual theologians or church leaders, but to all of us as human beings on account of our potentia oboedentialis, including members of other religions and atheists. Rahner warns of a condition, though:

\footnotetext{
${ }^{12}$ See also KNIEPS, Th. Die Unvertretbarkeit von Individualität, p. 50.

${ }^{13}$ PRÖPPER, Th. Theologische Anthropologie, vol. 1, p. 90.

${ }^{14}$ Schleiermacher (1768-1834) was the first theologian to implement the so-called "anthropological turn" in (Protestant) theology. This new approach was then endorsed by Liberal Theology through the 19th century and, notwithstanding the strong opposition of both dialectical theology and the Vatican's fight against modernism, it finally found resonance, around the mid-20th century in the Catholic Theology, too, and became, from then on, irrevocable in theology. Although the anthropological turn, strictly speaking, was actually carried through, in Catholic theology, not before Karl Rahner (1904-1984), authors like Maurice Blondel, Joseph Maréchal, Henri de Lubac and the Nouvelle Théologie must be mentioned as its precursors (PRÖPPER, Th. Theologische Anthropologie, v. 1, p. 97; 441).

${ }^{15}$ PRÖPPER, Th. Theologische Anthropologie, v. 1, p. 444.

${ }^{16}$ RAHNER, K. Theologie und Anthropologie, p. 43, own translation.

${ }^{17}$ LOSINGER, A. The Anthropological Turn, p. XXIX.
} 
"From the start we are interested not in ourselves as already actually theologians, but as beings to whose possibilities it belongs to become theologians, if the free unforeseeable message of God reaches us" (19/24/21) ${ }^{18}$.

Indeed, Rahner will insist throughout his whole life on this personal and relational dimension of revelation. One can interpret the Word of God so far as one is touched by it and remains in a relationship with God. For faith is primarily a relationship, not a theory or a system of valid statements. Given that the most basic assertion of Christian revelation is the unconditional and irrevocable assurance of God's love to every human being, even beyond death, a statement of such a depth and consequences cannot be simply held as valid, if it cannot be also experienced and verified in one's own life. Accordingly, the content of revelation must be anthropologically reasonable and comprehensible. Human knowledge of God cannot operate without making use of human analogies and taking account of human experience.

The relational dimension of revelation might become even more manifest if one bears in mind that, for Rahner, "Word" always implies Christ as well. What follows is that revelation may never be conceived of as the transmission of a piece of information. ${ }^{19}$ Besides helping us grasp the full range of the theological meaning of the expression "God's Word", this identification with Christ can be useful to focus on the most essential aspect of Christian revelation, which is a lively Word whom one can relate to and engage in conversation with, rather than a piece of information that can be heard and then kept aside.

\subsubsection{The Objectivity and Subjectivity of Revelation}

This leads us to a final distinction with regard to Rahner's conception of revelation on the basis of what has been seen. What could be distinguished is between the objective and the subjective elements of revelation, though solely on a theoretical level, since, in reality, they are but one act, the two sides of the one and same coin. Accordingly, one can speak of a "divine-human" revelation. As he later develops his understanding of revelation further, this original intuition will evolve into the distinction between transcendental and categorical revelation by virtue of the supernatural existential. However, as I see it, "Hearer of the Word" seems to contain already the germinal idea of this theory, even though this position may be contested ${ }^{20}$. Be that as it may, it is precisely this subtle distinction between the "objectivity" and "subjectivity" of revelation that has to be well understood, if one does not want to misunderstand Rahner or do injustice to his theology.

The key to understanding it resides precisely in the fundamental unity between these both elements of the one revelation. If, however, that which has been referred to as subjectivity of revelation is thought of simply as a human, immanent category, then Rahner's point has certainly been missed. Rahner was aware of the theological dilemma in which any definition of the transcendence of human spirit is caught. On the one hand, if the human spirit, which is essentially transcendence, cannot be said to be the locus where God can manifest himself, then one can no longer justify either an original orientation to God nor the philosophical possibility for a divine revelation. On the other hand, if the human spirit is necessarily and exclusively a locus of God's

\footnotetext{
${ }^{18}$ Translation from RAHNER. Hearer of the Word, p. 6, emphasis in original; just as quoted here, this formulation appears only in the 1963 edition, edited by Metz).

${ }^{19}$ BATLOGG, A. R. Glauben gibt zu denken, p. 91.

${ }^{20}$ For a different position, see KILBY, K. Karl Rahner, p. 60-69.
} 
revelation, one that must be understood as the sole fulfillment of human transcendence, as Scholastic theology conceived it, then it would be impossible to safeguard the freedom of both God and human beings ${ }^{21}$. The solution proposed by Rahner to that dilemma is a separation between transcendence and the "material" fulfillment of transcendence. For him, transcendence is undoubtedly an essential element of the human being by means of which a human relationship with God can at all be enabled. However, the fulfillment of human transcendence does not have to be a revelation of God. If it were so, God would be obliged to reveal himself and the character of God's unconditional freedom in revealing himself would go lost. Thus, even if God had chosen to keep silent, as he is unconditionally free, human transcendence would still be safeguarded ${ }^{22}$.

Still, if human transcendence does not have to materially be fulfilled by a revelation of God, the question arises why human being should at all listen to it. For Rahner, this difficulty can be solved only insofar as the act of human knowledge is grounded on the level of Being. By availing himself of Heidegger's theory of the ontological difference, he succeeds in placing both God and the human being on the same level of Being. This was the price to be paid, in order to liberate Being from being an entity and to "bring it down" into the realm of existence. This radical change does not divest God of his dignity, freedom or transcendence. On the contrary, what it does is to put special emphasis on existence and to ground the relationship between God and human beings on the level of Being. When two entities relate on the ground of Being, the apparent "strangeness" between them becomes relative.

Let us now try to illustrate it so that it may become sufficiently clear. If God, believed to be absolutely transparent to Being, manifests itself in history, he can only communicate what he is, what Being is, given that he is entirely in Being. And when the human being, in his quest of Being by way of her/his inquiring after it, hears this mediated Word of God, she/he, who is in the process of becoming transparent to her/ himself, to Being, will necessarily recognize that this Word has an absolute meaning for her/his existence. For an uttered, mediated Word is, originally, nothing but an appearance for others. As long as it remains an utterance, it is "out of Being", as it were. Only through human thinking and acting can this Word, then, come back into Being, reacquire its original meaning and significance $(64 / 68 / 76$; see also KNIEPS, 1995, p. 164-173) $)^{23}$. Yet, it should be remembered, this essential correspondence does not violate in any way the freedom, autonomy, and uniqueness of either God or the human being.

In addition to that, Rahner perceives an original, essential correspondence between Being and knowledge, inasmuch as both, in their widest and most essential sense, may be defined as being one with oneself (bei sich sein), being transparent to Being, clearedness (Gelichtetheit), self-possession (Selbstbesitz), and so forth (54/58/64). In a word, knowledge may thus be defined as reflexivity. If thus understood, both poles of the process of knowledge, namely objectivity and subjectivity, can be traced back to a single, original moment whence both the act of communication and the capacity of hearing emerge at once ${ }^{24}$. Having elucidated this fundamental aspect of Rahner's theory, the apparent contradiction between the so called objectivity and subjectivity of revelation should have been overcome.

\footnotetext{
${ }^{21}$ SIMONS, E. Philosophie der Offenbarung in Auseinandersetzung mit "Hörer des Wortes" von Karl Rahner, p. $42-43$.

${ }^{22}$ SIMONS, E. Philosophie der Offenbarung in Auseinandersetzung mit "Hörer des Wortes" von Karl Rahner, p. 45.

${ }^{23}$ See also KNIEPS, Th. Die Unvertretbarkeit von Individualität, p. 164-173.

${ }^{24} \mathrm{KNIEPS}$, Th. Die Unvertretbarkeit von Individualität, p. 167-69.
} 


\section{HEARING GOD'S WORD IN A SECULAR AGE}

The last task to be accomplished is now to draw some consequences from "Hearer of the Word" for a contemporary understanding of the interplay between divine revelation, human interpretation, and, particularly, theological enterprise. This shall be accomplished in two moments: a) the methodological modus operandi of theology as an academic discipline; b) the hermeneutic modus vivendi of believers in a secular age, insofar as every believer may be seen as a theologian, too.

\subsection{The Methodological Implications of "Hearer of the Word" for Theology}

In line with what has been said and considering the changing circumstances of our time, theology may be reckoned as an academic discipline and may maintain its status as such, only insofar as its presuppositions, fundamentals, and claims can be justified before reason..$^{25}$ Thus, the primary role of theology may be at best defined as rational mediation of faith. The major difficulty that arises from this task is its methodological implementation. After all, theology has to attribute absolute, universal meaning to a contingent manifestation (Lessing). Indeed, for the Catholic theologian Franz Schupp, this is a very complex issue to be tackled and certainly represents an "unexpected" turn in human history. As distinguished from Greek philosophy, the biblical approach is an attempt to understand God on the basis of history and the concrete person of Jesus Christ. So being, the aim of dogmatic theology is "to convey to every historical context, in a methodologically reflected form, the word 'God', just as it became comprehensible in Christ". ${ }^{26}$ If that is right, theology cannot be impartial, as other sciences strive to be, given that for any topic, theology has to develop a discursive reflection based on and taking account of the entire Christian tradition in complete conformity with the core of God's message as revealed in and through the person, life, and fate of Jesus of Nazareth. Actually, to keep biased and faithful to that original event, which is believed to be the absolute Word of God, rather than being harmful or disadvantageous for theology's scientificity and reasonableness, is the guarantee that its reflection on faith may preserve its original character of definitiveness despite the contingency and precariousness of human existence.

As for this task of theology, there seems to be no dissent among theologians. Most disagreement arises when it comes to the question how to methodologically carry out such a hermeneutic undertaking. For a long time, there prevailed the well-known model of a fruit's stone and flesh. Accordingly, dogmatic contents would be compared to a fruit stone (the nucleus), which remains unchangeable over the centuries, whereas the flesh (the form in which those contents are presented) would vary according to the context, language, culture, mindset, etc. Following this model, the task of dogmatic theology would consist both in recognizing what the nucleus of dogmas is and in the struggle to remain faithful to it, despite being amidst changing and contingent historical contexts.

For Schupp, however, this model contradicts the fundamental framework of biblical thinking ${ }^{27}$. He maintains that the consciousness of any given historical context cannot be deemed as an external and/or foreign aspect of dogma, but rather as an element "pertaining to the contents to be reflected by dogmatics themselves" ${ }^{28}$. In that way,

\footnotetext{
${ }^{25}$ KNAPP, M. Die Vernunft des Glaubens, p. 393.

${ }^{26}$ SCHUPP, F. Auf dem Weg zu einer kritischen Theologie, p. 43, own translation.

${ }^{27}$ SCHUPP, F. Auf dem Weg zu einer kritischen Theologie, p. 43-44.

${ }^{28}$ SCHUPP, F. Auf dem Weg zu einer kritischen Theologie, p. 43, own translation.
} 
consciousness does not represent an obstacle to dogmatic formulations, but a critical as well as innovative moment of faith. Precisely because of that, the practice of dialogue with other religions and secular individuals can provide theology with an ideal chance to "expand" its own consciousness and to grasp the contents of its own faith anew, if conceded that the heritage of those religious traditions is a legitimate part of the consciousness of humankind. As a consequence, only insofar as consciousness is included as a genuine moment of faith itself can it touch the depths of one's heart and become intelligible. Otherwise, God's revelation runs the risk of becoming an ideology or even remaining foreign to human mind.

This methodological observation is in line with Wenzel's view on the historical development of the discourse of theology. According to him, no discourse - and this applies all the more to theology - originates, evolves, and develops "out of nowhere". Mostly, the development of the discourse about God is determined by questions put from the outside having pretension to validity, too. Their repercussion on the theological discourse is such, that it cannot remain unchanged. Being so, he affirms that "[...] theology does not generate its development of its own accord - as though it would carry out a development program -, but rather owes to the provocation of questions coming from the outside" 29 . Therefore, if theology wants to be up to its job in this complex and plural world, to give an ear to the voices and challenges coming "from the world" and to take them seriously is a further task to be accomplished. For "[r] evelation does not have to be merely a critical judgment pronounced on what is human, merely something standing above the world, which can never become 'flesh' but always only a thorn in the flesh [...]" (226/216/274, translation from RAHNER, 1994, p. 154). If God's absolute Word wills to become flesh and be really heard, it has to become particular and contextual, reflected on and interpreted.

The biblical category used to lay bare the fallibility of any rigid dogmatic system and to make it clear that God is always greater than what has already been said and thought about him is the Kingdom of God. The reality of the Kingdom of God opens up new possibilities for history, for historical processes, and for human agency. It liberates human destiny from the arbitrariness of the (Greek) gods and introduces the categories of freedom and the "open-endedness" of history. Therefore, as Schupp sees it, this biblical way of thinking allied with the category of the Kingdom of God may be used to justify and urge critical thinking in theology. The reason provided by him is that they both are able to break the bonds of necessity that the Greek idea of law

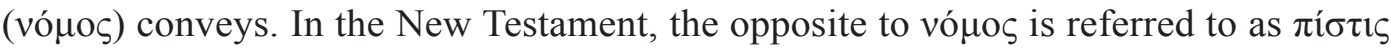
(faith), an act of human freedom before another freedom ${ }^{30}$.

Therefore, to raise its voice against any objectification of God so as to safeguard his absolute transcendence may be reckoned as a further unavoidable task of theology. Accordingly, to let one's thinking calm down in a comfort zone, as it were, or to lose oneself in speculative thoughts would mean the very perversion of theology. ${ }^{31}$ Besides corresponding to the core of biblical framework, this sort of critical thinking and "openendedness" is also in conformity with scientific method whose basic principle is also openness to the results and permanent criticism.

\footnotetext{
${ }^{29}$ WENZEL, K. Menschwerdung im Horizont der Welt, p. 178, own translation.

${ }^{30}$ SCHUPP, F. Auf dem Weg zu einer kritischen Theologie, p. 15.

${ }^{31}$ PEUKERT, H. Wissenschaftstheorie - Handlungstheorie - fundamentale Theologie, p. 60-61.
} 


\subsection{Religious Life in a Secular Environment}

In a world that has become secular, religious life, religious language, myths, and cults are no longer self-evident. A great hermeneutic effort of translation is required on the part of religions and, most particularly, of theology. The urgency of this need is expressed by Adorno as follows: "Nothing of theological content will persist without being transformed; every content will have to put itself to the test of migrating into the realm of the secular, the profane". ${ }^{32}$ Similarly, Habermas calls on religious people to make every endeavor to get their beliefs across by means of a rational, comprehensible language. After all, it is up to believers to ensure the precious treasures of religions against them becoming lost. For if they do, not only will believers lose something valuable, but the whole society, including non-believers. This may become clear through the following example provided by him: "As sin turned into guilt, as trespasses against divine commandments turned into violation of human laws, something became lost"33.

Now, one does not have to be a professional translator or a theologian to know how difficult and complex such work of translation actually is. Many are the voices that even hold it to be an unrealistic project, given the impossibility of translating central religious notions such as redemption, sin, revelation, grace, salvation, karma, moksha, nirvāṇa, and so on without their semantic meaning going lost or, perhaps, "migrating" into something else.

On the other hand, the great philosopher Paul Ricoeur draws attention to the fact that translations between languages, cultures, and religions do not emerge exclusively out of a (pragmatic) need, as it appears to be the case in Habermas' proposal, insofar as such translation efforts would meet the need of getting the deepest concerns of different religious groups across in a plural society. Instead, what Ricoeur points out in one of his essays on this matter is that beyond the pragmatic task of mediating between words and worlds, the translator is also inhabited by a desire to translate, which is "more tenacious, more profound, more hidden" than the former. ${ }^{34}$ The desire to translate emerges out of a drive to convey what one has understood. For, according to Ricoeur, to translate means primarily to understand. Thus, before one translates something into a foreign language, one has to have understood it oneself, one has to have translated it first to oneself. Accordingly, one can speak of both an inner and an outer translation. ${ }^{35}$ It follows that such a hermeneutic endeavor is not demanded from believers or theologians in their relations with the "outer world", but within their linguistic community, too.

This being the case, it may be said that believers can, nowadays, no longer escape the unavoidable task of engaging in hermeneutic work, be it for the sake of their own communities, that is, for the perpetuation of their religious tradition, be it for their own sake, inasmuch as this is the only manner to maintain one's faith lively and meaningful. But all that is only possible "if the free unforeseeable message of God reaches us (19/24/21)". This is, in fact, the sine qua non of religious and theological life. If the Word of God has not yet reached us in our innermost, or rather, if we have not yet listened to this Word first-hand, if this Word has not been uttered in a personal relationship with God, then even hermeneutic attempts may fail to achieve their goal, since the most essential element of Christian revelation would be missing. For the

\footnotetext{
${ }^{32}$ ADORNO, Th. W. Reason and Revelation, p. 136.

${ }^{33}$ HABERMAS, J. Glauben und Wissen, p. 21-24, quote on p. 24, own translation.

${ }^{34}$ RICOEUR, P. On Translation, p. 21.

${ }^{35}$ RICOEUR, P. On Translation, p. 24-25.
} 
primary purpose of Christian revelation is to bring each person into communion with God. The Second Vatican Council expresses that conviction as follows: "Through this revelation, therefore, the invisible God out of the abundance of His love speaks to men as friends and lives among them, so that He may invite and take them into fellowship with Himself $(D V 2) . "$

\section{OUTCOME}

Rahner's philosophic-theological reflection has persuasively shown that neither can the apparent contradiction between theology and the variety of sciences be said to be the case, nor the one between the heteronomy of divine revelation and human autonomy for one's self-determination. If thought about on a metaphysical plane, all those superficial discrepancies appear to converge in the realm of Being whereby true and essential knowledge is rendered possible. But this process of becoming transparent to Being, of becoming one with oneself, has to begin in one's inwardness by inquiring after Being, since there is no essential knowledge without (self)reflection. In her/his transcendental, unlimited openness to Being, and by way of inquiring after it, the human being, through her/his potentia oboedentialis, can hear the absolute, though historically mediated, Word of God and thus (re)gain access to Being. This being the case, human transcendence grounds a fundamental relation between God and human beings by means of which a free divine revelation is possible, insofar as this Word can only be uttered and heard in complete freedom.

Bearing that in mind, one can say that the human Being is a locus par excellence of revelation. It is in the human spirit that God's will to reveal his incommensurable love and the need of human beings to fulfill their unlimited transcendence meet. Only within a personal relationship can the Word of God really become a Word of life, rather than merely "a thorn in the flesh" (RAHNER, 226/216/274). Furthermore, this message is addressed precisely to the human being. If that is correct, one's personal relationship with God, in which the Word is uttered, is to be accorded, in the present time, much more emphasis and primacy.

The question then arises how can the subject articulate such 'experience of God' in a way that preserves the particularity of one's own understanding of the Word and, at the same time, does justice to the absolute otherness of such Word, thereby remaining a sovereign act of God's free will. Hence the valuable role of theology, as an academic discipline, in mediating and translating between these different spheres. Such translation efforts have a threefold purpose: a) they make possible the communication with secular, plural societies and minimize the chances of religions being reduced to a private affair; b) they make the content of revelation more plausible to believers themselves in the face of the changing circumstances; c) they reduce the apparent antinomy between lifeworld and belief, though, thereby not eliminating, of course, the "eschatological reserve".

Whether a dialogue between theology and the modern world can take place on the metaphysical plane, as suggested by Rahner, is, of course, arguable. Be that as it may, it is extremely necessary that both engage and keep in a serious and productive dialogue which can only be conducted through mutual recognition. And the Word of God shall be heard in that ongoing dialogue, provided that both sides are open, authentic, committed to the truth, and meet at least on the level of human existence, if not of Being. 


\section{REFERENCES}

ADORNO, Theodor W. "Reason and Revelation." In Critical Models: Interventions and Catchwords, translated by Henry W. Pickford, p. 135-42. Columbia University Press, 2012.

BATLOGG, Andreas R. Glauben gibt zu denken: „Geist in Welt“ und „Hörer des Wortes“. In: Der Denkweg Karl Rahners: Quellen, Entwicklungen, Perspektiven. Edited by Andreas R. Batlogg, $2^{\text {nd }}$ ed. Mainz: Matthias-Grünewald, 2004. p. 55-105.

CASANOVA, José. Public Religions Revisited. In: Religion: Beyond a Concept. Edited by Hent Vries. New York: Fordham University Press, 2008. p. 101-19.

CASANOVA, José; JOAS, Hans. Religion und die umstrittene Moderne. Stuttgart: Kohlhammer, 2010 .

FISCHER, Norbert. Die Gottesfrage im Denken Martin Heideggers. Meiner, 2011.

GREINER, Friedemann. Die Menschlichkeit der Offenbarung: die transzendentale Grundlegung der Theologie bei Karl Rahner. München: Chr. Kaiser, 1978.

HABERMAS, Jürgen. Glauben und Wissen. Friedenspreis des Deutschen Buchhandels. Frankfurt am Main: Suhrkamp, 2001.

JOAS, Hans; WIEGANDT, Klaus (Ed.). Säkularisierung und die Weltreligionen. Frankfurt am Main: Fischer Taschenbuch, 2007.

KILBY, Karen. Karl Rahner: Theology and Philosophy. Routledge, 2004.

KNAPP, Markus. Die Vernunft des Glaubens: Eine Einführung in die Fundamentaltheologie. Freiburg im Breisgau: Herder, 2009.

KNIEPS, Thomas. Die Unvertretbarkeit von Individualität: Der Wissenschafts-Philosophische Ort Der Theologie Nach Karl Rahners “Hörer Des Wortes”. Bonner Dogmatische Studien 19. Würzburg: Echter, 1995.

LOSINGER, Anton. The Anthropological Turn: The Human Orientation of Karl Rahner. New York: Fordham University Press, 2000. <https://doi.org/10.5422/fso/9780823220663.001.0001>.

MARTIN, David. On Secularization: Towards a Revised General Theory. Aldershot: Ashgate, 2005.

PEUKERT, Helmut. Wissenschaftstheorie - Handlungstheorie - fundamentale Theologie: Analysen zu Ansatz und Status theologischer Theoriebildung. Frankfurt am Main: Suhrkamp, 2009.

PRÖPPER, Thomas. Theologische Anthropologie. Freiburg im Breisgau: Herder, 2011. 2 v.

RAHNER, Karl. Hearer of the Word: Laying the Foundation for a Philosophy of Religion. Edited by Andrew Tallon. Translated by Joseph Donceel. New York: Continuum, 1994.

. Hörer des Wortes: Schriften zur Religionsphilosophie und zur Grundlegung der Theologie.

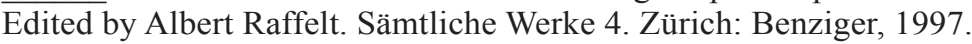

Hörer des Wortes: Zur Grundlegung einer Religionsphilosophie. Edited by Johannes Baptist Metz. München: Kösel, 1963. 1941. Hörer des Wortes: Zur Grundlegung einer Religionsphilosophie. München: Kösel \& Pustet,

Theologie und Anthropologie. In: Schriften zur Theologie. Einsiedeln; Zürich; Köln: Benziger, 1967. Vol. 8, p. 43-65.

RICOEUR, Paul. On Translation. Translated by Eileen Brennan. London: Routledge, 2006.

SCHUPP, Franz. Auf dem Weg zu einer kritischen Theologie. Freiburg im Breisgau; Basel; Wien: Herder, 1974.

SIMONS, Eberhard. Philosophie der Offenbarung in Auseinandersetzung mit "Hörer des Wortes" von Karl Rahner. Stuttgart; Berlin: Kohlhammer, 1966.

WEGER, Karl-Heinz. Karl Rahner: eine Einführung in sein theologisches Denken. Herderbücherei 680. Freiburg im Breisgau; Basel; Wien: Herder, 1978. 
WENZEL, Knut. Menschwerdung im Horizont der Welt: Bildungshandeln in schöpfungstheologischer Resonanz. In: “... und nichts Menschliches ist mir fremd”: Theologische Grenzgänge. Edited by Ottmar John and Magnus Striet, Ratio fidei 41. Regensburg: Friedrich Pustet, 2010. p. 175-96.

Recebido em: 19/05/2018

Aprovado em: 22/06/2018

\section{Correspondência para:}

Prof. Dr. Leandro Luis Bedin Fontana

Pestalozziring 12

55250 Zornheim

Alemanha 